\title{
對페루 USAID 협력사업 현황
}

\section{I . 사무소 설치 및 인력현황}

1962년 사무소 설치, 2 층 건물을 사무소로 사용중

ㅁ사무소 인력은 143 명 (원조전략·계획수립, 사업 평가, 정업무처리 등)

- 19명은 USAID 직원(외교관 신분)

- 6 명은 여타국 전문가(계약)

- 118명은 계약직(현지인, 미국인)

\section{II. 사업 추진경과}

ㅁ 1933년부터 대 페루 협력사업 추진

- Roosevelt 대통령의 미국과 라틴아메리카간

'Good Neighbor' 정책에 의거 실시

1940 50년대, Institue of Inter American Affairs, Inter American Health/Food Production Cooperative Service 등을 통해 협력
사업 추진

ㅁ1952년 기술협력 협정 체결

ㅁ 1962년 USAID 페루사무소 설치(1961년 USAID 설립)

1960년대, 농업개발, 의료보건 개선, 식량지원 중 점 지원

ㅁ 1970년대, 농업개발 및 농촌개발 중점 지원, 외에 주택개량, 국민건강, 산림녹화 지원

ㅁ1980년대, 밀림지역 개발, 농업기술향상, 발전시 설, 의료보건, 상하수도 중점 지원

ㅁ 1990년대, 빈곤퇴치, 의료보건개선, 마약퇴치, 경 제체제전환, 인권보호 중점 지원

\section{III. 사업발굴 및 추진절차}

마업발굴:사업발굴을 위한 분야별 technical team (팀별 인원은 대략 5 6명 / 미국인 1 2명, 현 
지인 3 5명) 운영

ㅁ추진절차

- 대 페루 5 개년 원조전략 작성, 행정부 승인

- 동원조전략 하에 페루 정부와 중점 지원부문별 5 개년 지원계획에 관한 Macro Agreement 체결 - 페루 정부와 개별 프로젝트에 대한 Agreement 체결

\section{IV. 중점지원분야(Sector)}

ㅁ중점분야:민주주의 강화, 경제발전, 의료보건여 건 개선, 환경보호, 교육여건 개선, 마약퇴치, 페루 에쿠아돌 국경지원

ㅁ분야별 주요 프로그램

- 민주주의강화:지방정부 기능강화 및 지방분권 화, 공공부문개혁 및 제도정비, 공정한 선거제 도 확립

- 경제발전:무역투자제도 개선, 지적재산권 강 화, 관세제도 개선, 의료보건 · 의료보건시스템 개선, 가족계획 프로그램 지원, 모자보건 여건 향상 및 유아 건강 증진, 젼염병 예방 및 관리

- 환경보호:산림녹화, 자원보존지역 보호, 희귀 동식물 보호, 산림 보호

- 교육:초중등교사 연수, 공공 교육제도 및 규정 정비, 농촌 지역 교육여건 개선

- 마약퇴치: 코카재배 퇴치, 소규모 인프라건설, 경제작물 재배기술교육, 마약퇴치 관련기관 능 력강화
- 페루 - 에쿠아돌 국경지원 : 국경지역 통신, 도 로 등 인프라건설, 국경지역 무역 및 투자증진, 국경지역 관세제도 개선 등

\section{V. 지원규모}

ㅁ금년도 : 100백만불(무상지원규모)

- 차관지원 사업은 실시하지 않음.

- 페루에 대한 제 1 원조공여국

※ 국가별 지원규모는 국회에서 결정

ㅁ 연도별 지원규모:2003년 145백만불, 2004년 114 백만불

\section{VI. 사업추진방법}

ㅁㅜㅜㄹㅗ 프로젝트사업 형태로 사업을 추진하며, 연수 생초청은 대사관에서 실시, 전문가 파견은 매우 미미

므로젝트사업의 주 내용은 페루 내에서의 Capacity Building 및 인프라 구축(연수생초청과 전문가파견 지양)

ㅁ사업 시행업체는 사무소에서 입찰을 통해 선정 - 사업별 전문기관, 국내외 $\mathrm{NGO,} \mathrm{미국인} \mathrm{업체,}$ 페루인 업체 등 입찰에 참여 제한 없음.

- 사무소에서는 모니터링, 평가 실시 및 본부에서 감리단 파견, 감리 실시 


\section{VII. 시사점}

ㅁ원조기관으로서의 경쟁력 강화 및 사업효과를 더욱 제고하기 위해서는 매년 대 페루 협력사업 규모 확대 및 중장기 원조전략 수립, 중점 지원 분야 선정과 동 분야에 대한 집중적, 장기적 지 원이 요구됨.

ㅁ우수사업 발굴을 위해서는 페루 요청에 의한 사업 발굴에서 벗어나 중점 지원 분야에 대한 전문가단 파견 또는 사무소 인력 증원을 통한 주도적, 체계 적인 사업발굴이 필요하며, 중장기 차원의 지원계 획 수립을 위한 양국간 협의회 운영에 대한 검토가 요망됨.

[자료:주페루 KOICA사무소] 